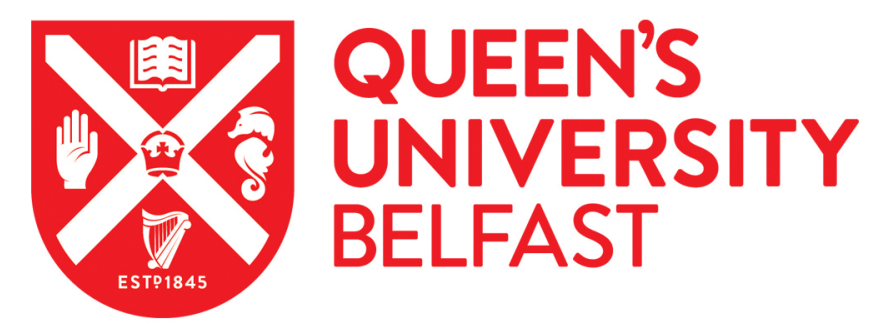

\title{
Outsmarting the gig-economy through collective bargaining - EU competition law as a barrier to smart cities?
}

Schiek, D., \& Gideon, A. (2018). Outsmarting the gig-economy through collective bargaining - EU competition law as a barrier to smart cities? International Review of Law, Computers And Technology, 32(2-3), 275-294. https://doi.org/10.1080/13600869.2018.1457001

Published in:

International Review of Law, Computers And Technology

Document Version:

Peer reviewed version

Queen's University Belfast - Research Portal:

Link to publication record in Queen's University Belfast Research Portal

Publisher rights

Copyright 2018 Taylor \& Francis. This work is made available online in accordance with the publisher's policies. Please refer to any applicable terms of use of the publisher.

\section{General rights}

Copyright for the publications made accessible via the Queen's University Belfast Research Portal is retained by the author(s) and / or other copyright owners and it is a condition of accessing these publications that users recognise and abide by the legal requirements associated with these rights.

Take down policy

The Research Portal is Queen's institutional repository that provides access to Queen's research output. Every effort has been made to ensure that content in the Research Portal does not infringe any person's rights, or applicable UK laws. If you discover content in the Research Portal that you believe breaches copyright or violates any law, please contact openaccess@qub.ac.uk. 


\title{
Outsmarting the gig-economy through collective bargaining- EU competition law as a barrier to smart cities?
}

\author{
Dagmar Schiek, School of Law, Senator George Mitchell Institute for Global \\ Peace, Security and Justice, Queen's University Belfast and Andrea Gideon, \\ School of Law and Social Justice, University of Liverpool
}

\begin{abstract}
In August 2016, drivers delivering meals in London after being booked via the platforms 'Deliveroo' and 'UberEATS' made headlines by challenging working practices in the gig-economy through collective industrial action. Dissatisfaction resulted from extremely low levels of pay as well as a new payment calculation system being introduced without consultation. This indicates that the 'gig-economy', though arguably contributing to 'smart cities', may not always constitute the smartest solution for those serving within it. However, it also highlights that collective industrial action is far from structurally impossible for workers in the 'gig-economy', even though management of labour relies on anonymous and automated micro-management through internet platforms and apps. Indeed, collective organisation may seem the smartest solution for upgrading the gig-economy for its workers. This article develops an original contribution to the interface of smart technology in the gig-economy, collective labour rights, and EU competition law. We identify that EU competition law as interpreted by the Court of Justice would hinder collective organisation of those serving the gig-economy and develop a comprehensive re interpretation which allows adaptation of EU competition law to smart employment markets.
\end{abstract}

\section{Introduction}

Notwithstanding the lack of a clear definition of 'smart cities', the smart city is built on smart uses of information technology (IT) ${ }^{1}$ and internet-based platforms for its governance, ${ }^{2}$ utilising data created by citizens to improve efficiency. Smart usage of IT and e-communication are also the base of the

\footnotetext{
*A more encompassing version of this paper has been presented at the 3rd Labour Law Research Network Conference (Toronto 2017, where Andrea Gideon's participation was enabled by the LLRN travel fund) and the 24th Conference of Europeanists "Sustainability and Transformation" (Glasgow 2017). We are grateful for written feedback on the conference paper by Albert Sanchez-Graells and Luca Ratti, to Joanna Unterschütz for convening the panel on "Collective bargaining transformation for sustainability" for the CES, for informal feedback by many of the discussants for both conferences, including Eva Brameshuber, Stein Evju, Julia Lopéz Lopéz and Tonia Novitz, and the suggestions by this issues editor and the anonymous referees. The usual disclaimer applies.

${ }^{1}$ (Cocchia, 2014; Glasmeier \& Christopherson, 2015; Almirall, et al., 2016).

2 (Almirall, et al., 2016) p. 142.
} 
"gig-economy", ${ }^{3}$ a term we use as an umbrella for several internet-based methods of allocating services to those consuming them. As smart cities, the gig economy utilises information technology for data management in order to improve work efficiency. The gig-economy and smart cities are thus closely related ${ }^{4}$ not least as the gig-economy is markedly prevalent in areas of particular relevance for urban life: individual transport (crucial for cities in regions with under-developed public transport especially), short term housing, domestic services including cleaning, child-care, mobile meals, elderly care and pet-care, and delivery services competing with or replacing public postal services.

In utilising the potential of enhanced communication and data processing offered by information technology, smart cities and the gig-economy harbour the risk of enhancing control ${ }^{5}$ and disempowerment. ${ }^{6}$ Labour law critique of the gig economy ${ }^{7}$ exposes the recurrence of extremely casual, precarious and exploitative working conditions reminiscent of the early industrial age. ${ }^{8}$ However, the use of information technology also offers the potential of a collaborative world of work and life where technology serves the enhancement of self-determination, ${ }^{9}$ conjuring the vison of smart cities establishing a 'commons-based' gig-economy for public uses. ${ }^{10}$

For realising this positive potential of both the gig economy and the smart city, the question in how far gig-workers are able to shape their conditions of work in order to achieve humane standards is crucial. Within the sphere of employment law, the right of workers to organise collectively provides the opportunity to achieve just that. Authors embracing the opportunities of the gig-industry tend to suggest that employment law needs to adapt to the new demands of the gig world. ${ }^{11}$ However, the same authors embrace the value of giving gig-workers (or micro-entrepreneurs) voice in their working environment. ${ }^{12}$ Beyond detailed discussion of social protection for gig workers, ${ }^{13}$ there is as yet scant discussion on how the options of collective bargaining rights for gig-workers are impacted upon by competition law.

\footnotetext{
${ }^{3}$ We use the term "gig-economy" in line with the recently agreed ILO report on non-standard work (ILO, 2016) instead of terms such as 'sharing economy' and 'collaborative economy', which may suggest a solidarity-based operation of business per se (on the fallacy of the terms see also (Kenney \& Zysman, 2016) p. 62).

${ }^{4}$ See for example (Almirall, et al., 2016), who discuss the "sharing economy" as a potential basis for smart city developments.

${ }^{5}$ (Sadowski \& Pasquale, 2015)

${ }^{6}$ (Cardulllo \& Kitchin, 2017)

${ }^{7}$ In lieu of even attempting to provide full coverage of the digital economy, here is a subjective choice: (Aloisi, 2016; Degryse, 2016; Sundararajan, 2016; Valenduc \& Vandrame, 2016; de Stefano, 2016; Hatzopolous \& Roma, 2017; Ratti, 2017); a useful literature review is provided in (Schmid-Drüner, 2016).

${ }^{8}$ Finkin (2016) highlights historical parallels to early capitalism, while Eurofund (2015) locate the phenomenon in the wider context of casualisation. Sadowski and Pascale (2015) criticise the "resurrection of early capitalist piecework in the guise of the gig economy".

${ }^{9}$ Sadowski \& Pascale (2015)demand a new dimension of the right to the city, while Cardullo \& Kitchen (2017) adopt Arnstein's ladder of citizen participation to the world of new technology, developing the requirements for empowering citizens to become collective co-decision makers by utilizing the emancipatory potential of technology.

${ }^{10}$ (Almirall, et al., 2016, pp. 141-151)

11 (Taylor, et al., 2017; Sundararajan, 2016)

12 (Taylor, et al., 2017, p. 77)

${ }^{13}$ See for example (Forde, et al., 2017) with numerous references.
} 
This article aims to fill that gap, by analysing the barriers posed by EU competition law for collective labour rights of gig-workers. Again, this is reminiscent of the early industrial age where workers, perceived as free from any protection, were subjected to new legislation criminalising their collective organisation (then termed "combination"). ${ }^{14}$ Similarly, today's gig-workers, if viewed as independent entrepreneurs, are barred from collective bargaining by competition law. In today's EU, the complexity of the situation is enhanced by legislative competences meandering between national levels (which retain the competence for regulating the law of industrial conflict) and EU levels (where legislative competence for collective organisation of employers and employees is shared between the EU and its Member States, while EU competition law is an exclusive EU competence). We argue that there is a case for all gig-workers, independent of formal status, to be able to avail of collective bargaining rights, and consequently challenge the desirability and necessity of enforcing competition law against them. Using EU competition law as an example for competition law regimes more generally, we develop an original re-interpretation of its categories, arguing that in the European Union with its enhanced socio-economic model gig-workers can and should be granted realistic opportunities to bargain collectively and to threaten their employers with collective action.

The paper will proceed as follows: We will first sketch very shortly the basic features of the gig-economy and distinguish two forms of organisation. Subsequently, we will summarise the extent to which collective bargaining is excluded from the application of EU competition law under the case law as it stands currently. This will be followed by a conceptual discussion of whether collective organisation and bargaining can be of use for micro-entrepreneurs of the gig-economy. Based on the rationale for such strategies, we will develop arguments for aiming to preserve scope for gig workers to improve their working conditions collectively in future case law.

\section{Work in the gig-economy - Between app-based match-making for real-world work and crowd-sourced IT-work}

The gig-economy is mainly characterised by the extensive use of IT for the distribution, allocation, evaluation, grading and payment of work. The literature distinguishes two main organisational models as archetypes; app-work and crowd work. ${ }^{15}$ The first archetype, epitomised by "Uber", uses technology to match customers with persons delivering work in the real world, such as offering a ride (cab services), delivering items (courier services), caring for children, the elderly or pets, gardening, or other craft services. The second archetype consists of ICT based work, such as designing a web page, typing text or numbers into forms (e.g. for billing services), contacting customers, or even working the "apps" for app work. IT is used in order to source this work from an anonymous group of "bidders", who are referred to as the crowd, hence the name crowd sourcing.

Work of the first archetype can appear as an IT platform matching those seeking a service (e.g. individual transport) with an independent provider (e.g. the Uber taxi). However, typically the platform "app" provides more functions. In the case of Uber, it determines the price for the specific ride, with the help of an algorithm that emulates market mechanisms and demands higher prices at busy times. Uber also encourages rating of drivers, and thus operates a system of constant evaluation and

\footnotetext{
${ }^{14}$ See, for example, the British Combination Act of 1799 as cited in (Aspinall \& Smith, 1959, p. 749).

${ }^{15}$ See, for example, (Cherry, 2016; ILO, 2016).
} 
grading, linked to the threat of de-activation if ratings are too low. Finally, the payment of the service is channelled through Uber: the rider does not pay the driver, but instead the price for the ride is cashed in electronically, a profit margin for Uber is deducted and the remainder transferred to the driver - if the system works correctly. Basically, Uber offers a transport system without registered drivers, at a price much lower than taxi rides and with wages below those taxi drivers achieved before Uber became established. Systems offered under different names and with some variation include Lyft (another taxi service), Deliveroo (a food delivery service) and Citylift (a bicycle couriering service). ${ }^{16}$

The second archetype, crowd-working, ${ }^{17}$ creates virtual bidding platforms for services, to be delivered electronically, via the internet. These can be services requiring low or high qualification - the relevant platforms comprise translation services, the writing and/or evaluating of bills, constructing or maintaining web pages, but also providing legal or other professional advice. Often, but not always, crowdsourcing goes along with the splitting up of work processes in micro processes. Crowdworking platforms may entail instruments to evaluate crowd workers. Frequently they allow the one who invites bids, or the delivery of work, to reject work, which means that time spent on providing a service remains unremunerated. Typical tradenames for low qualified work, including micro-processes, comprise Amazon Turk, Rapidworkers, Microworkers (the last two mainly on computerbased tasks) and those rumoured to crowd-source higher qualified work include Axiom for lawyers. ${ }^{18}$ The construction of this type of web platform may be closer to a brokering system than "app work". Frequently, the service provider and the worker will not have direct contact, because the administration of bidding, delivery and payment is organised via the web page. In contrast to "app work", there may be more cases where the web site provider only streamlines the offers and demand instead of generating the service.

The two archetypes represent points on a continuum. Therefore, not every single working arrangement will fall neatly into either category, but may be somewhere in between and it is not impossible that yet other forms may arise in the future. Since it is not our main purpose to contribute to the growing literature on gig worker classification, this brief summary may suffice. However, as will be shown below, the categorisation of the service providers as workers or otherwise is relevant for the question whether gig workers can engage in collective bargaining without clashing with EU competition law. In this regard the differentiation between the two archetypes plays a certain role: app-work (the matching of customers and workers for physical tasks such as cleaning, care provision, individual transport or delivery) seems more prone to being classed as an employment relationship, as is

\footnotetext{
${ }^{16}$ For a more extensive analysis of different models of app work see (Cherry, 2016; Aloisi, 2016).

17 See on this (Berg, 2016; Aloisi, 2016), see also (Finkin, 2016), for a selective comparison see (Waas, et al., 2017).

${ }^{18}$ Their webpage explicitly acknowledges that some of the providers may be employees (Huws, et al., 2016).
} 
also witnessed by case law. Cases have proliferated in the United States ${ }^{19}$ and, recently, UK employment tribunals having classed Uber drivers ${ }^{20}$ as well as cycle deliverers for City Sprint ${ }^{21}$ as employees. While crowdsourcing has also spawned litigation, ${ }^{22}$ this litigation has less frequently resulted in establishing employee status for those servicing the gig industry. Notwithstanding considerable intensity of exploitation in the crowd sourcing industry, the fragmentation of tasks under this type of gigwork also leads to the option for workers to engage with a larger number of customers. As long as the crowd-sourcing platform does not limit this form of multiple customer servicing, the gig worker may be able to secure a degree of independence from any individual customer. Accordingly, $r$ some of these workers may be truly self-employed persons. ${ }^{23}$ The conclusion to be drawn for our purposes is thus that a considerable number of gig-workers could be classed legally as truly self-employed. ${ }^{24}$

\section{EU competition law and collective bargaining - the case law}

The ECJ case law constitutes one example for approaches to competition law perceiving inherent tension between collective labour rights and competition law concepts such as the bans on cartels and on abusing a dominant market position. First, collective agreements could be viewed as limiting competition between individual workers as well as, in cases of multi-employer bargaining (i.e. if several employers or employer associations are party to a collective agreement), collective agreements may be classified as a collusion (i.e. a cartel) between undertakings to not compete on the price of labour. ${ }^{25}$ Second, multi-employer bargaining, in particular if coupled with the option to extend a collective agreement for general application, may contribute to the creation of institutions (e.g. social security institutions) holding a dominant market position, which may then be fined on the grounds of abusing such a dominant position.

The subsequent sub-sections analyse under which circumstances the Court of Justice of the European Union (ECJ) considers labour agreements as anti-competitive collusion or cartels (1) or as leading to an abuse of market dominance (2). We will then turn to the position of micro-entrepreneurs more specifically (3).

\footnotetext{
${ }^{19}$ Cherry (2016).

${ }^{20}$ Aslam and Farrar v Uber B.V, Uber London Ltd, Uber Britannia Ltd, 28 October 2016 Case No 2202550/2015, appeal dismissed by the EAT on 10 November 2017 (UKEAT/0056/17/DA. Uber unsuccessfully sought to have its action joined with the Pimlico Plumbers case, which is heard before the Supreme Court at the time of writing (see Jane Croft, Financial Times, 19 February 2018). In a hearing before ACA, Deliveroo drivers accepted that they do not enjoy worker status for the purposes of collective bargaining (https://www.gov.uk/government/uploads/system/uploads/attachment data/file/663126/Acceptance Decision.pdf).

${ }^{21}$ Dewhurst $v$ Citysprint UK Ltd, 17 January 2017, Case No 2202512/2016, the appeal was not pursued by the employer, who only changed conditions for the claimant in response to the ruling (see https://www.guardian.com/business/2017/nov/15/citisprint-employment-rights-courier-minimum-wage-holiday-pay).

${ }^{22}$ Christopher Otey, et al. v. CrowdFlower, Inc., et al., Case No. 12-5524 which ended in a settlement. See for a summary Lexis Legal News, 'California federal judge approves modified settlement in 'crowdsourcing' wage suit' Lexis Legal News (10th August 2015) <https://www.lexislegalnews.com/articles/1555/california-federaljudge-approves-modified-settlement-in-crowdsourcing-wage-suit> accessed 6th November 2017.

${ }^{23}$ For a similar result see (Ratti, 2017).

${ }^{24}$ (Aloisi, 2016; Hatzopolous \& Roma, 2017; Ratti, 2017; Taylor, et al., 2017).

${ }^{25}$ For more detail on this, see (Schiek \& Ulber, 2016; Schiek, et al., 2015, pp. 71-72).
} 


\title{
1. Collective agreements as anti-competitive collusion ("cartel")?
}

The ECJ's first ruling ${ }^{26}$ on collective bargaining and competition law arose in criminal proceedings against ship-owners using non-recognised dock workers in Ghent harbour in order to avoid paying the wages owed to recognised dock workers, whose working conditions were 'governed by collective labour agreements concluded [...] and made mandatory by Royal Decree'. ${ }^{27}$ In deciding whether these collective labour agreements collided with EU competition law, the Court refused to class dockers as undertakings, because they concluded fixed term employment contracts with ship owners.

\begin{abstract}
26 It must therefore be concluded that the employment relationship which recognised dockers have with the undertakings [...] is characterised by the fact that they perform the work in question for and under the direction of each of those undertakings, so that they must be regarded as 'workers' within the meaning of [Article 45 TFEU] [...]. Since they are, for the duration of that relationship, incorporated into the undertakings concerned and thus form an economic unit with each of them, dockers do not therefore in themselves constitute 'undertakings' [...]. [emphasis added]

\section{It should be added that, even taken collectively, the recognised dockers in a port area cannot be regarded as constituting an undertaking.}

Therefore, Becu established that employees in an employment relationship are not undertakings for the purposes of EU competition law due to being incorporated into their employers' organisation. ${ }^{28}$

Somewhat puzzlingly, the Court did not refer to Becu in the landmark Albany ${ }^{29}$ and two parallel cases, ${ }^{30}$ decided only five days later, which initiated a line of case law establishing a limited exclusion of collective bargaining from Article 101 TFEU. While these cases were widely discussed academically, ${ }^{31}$ the Commission did not pursue the application of competition law to collective agreements beyond this limited exclusion. Considering that work is becoming ever more precarious, this constitutes a missed opportunity for extending collective representation and collective bargaining, with particular relevance for the gig-economy. It is thus worthwhile to recount the development of this case law in order to identify the risks for emerging collective activities of gig-workers.

The three cases of September 1999 concerned collective agreements establishing social security institutions made compulsory for the relevant sector by administrative order. The employers rejected compulsory affiliation to the collectively agreed schemes, and challenged these obligations with reference to Articles 101 and 102 TFEU (prohibition of cartels and of abusing a dominant market position respectively). The ECJ failed to recognise a general competition law immunity of collective

\footnotetext{
${ }^{26}$ Four years earlier, the Van Schijndel case(C-430-1/93, judgment of $14^{\text {th }}$ December 1995) touched upon the competition law compatibility of a social security scheme for physiotherapists similar to that at stake in the Albany case discussed below. However, for procedural reasons the Court did not discuss the substance of this problem.

27 Judgment of 16 ${ }^{\text {th }}$ September 1999, Becu C-22/98 EU:C:12999:419, paragraph 25.

${ }^{28}$ See also (Jones \& Sufrin, 2016, p. 125; Wish \& Bailey, 2015, p. 93).

${ }^{29}$ Albany, C-67/96 EU:C:1999:430.

${ }^{30}$ Brentjens C-115-117/97, EU:C:1999:434, Drijvende Bokken C-219/97, EU:C:1999:437.

${ }^{31}$ E.g. (Bruun \& Helsten, 2001), more sources in (Schiek \& Ulber, 2016), on specific application to the "gigeconomy" see (Lougher \& Kalmanowicz, 2016).
} 
agreements, in contrast to Becu. Yet, it neither followed AG Jacobs' extreme proposal that only collective agreements on core employment conditions (not including occupational pension funds) should be excluded from the ban on cartels. Instead, the ECJ reasoned that while "certain restrictions of competition are inherent in collective agreements between organisations representing employers and workers, [...] the social policy objectives pursued by such agreements would be seriously undermined if management and labour were subject to Article [101(1) TFEU] when seeking jointly to adopt measures to improve conditions of work and employment." ${ }^{\prime \prime 2}$ The Court recalled that Articles 152, 154 TFEU supported cooperation between Member States in relation to collective bargaining rights as well as encouraging dialogue between management and labour at EU level, potentially leading to agreements, ${ }^{33}$ and inferred from "an interpretation of the provisions of the Treaty as a whole which is both effective and consistent that agreements concluded in the context of collective negotiations between management and labour in pursuit of such objectives must [...] be regarded as falling outside the scope of Article [101(1) TFEU] [emphasis added]." In order to profit from that exclusion, collective agreements must fulfil two conditions:

1. they result from "collective negotiations between organisations representing employers and workers" 34 and

2. have the purpose to "jointly adopt measures to improve conditions of work and employment". ${ }^{35}$

The 'Albany formula' was repeated verbatim in the two parallel cases, and confirmed and specified subsequently.

The first criterion will be considered in more detail below, as it is the main difficulty for excluding collective agreements in favour of gig workers from EU competition law. The second criterion, relating to the purpose of the agreement, has been less problematic due to a broad interpretation ${ }^{36}$ by both the ECJ and the EFTA Court. The ECJ held in van der Woude $e^{37}$ that subcontracting a collectively agreed occupational health scheme did not undermine the Albany exclusion because "such a limitation would constitute an unwarranted restriction on the freedom of both sides of industry". Similarly, the EFTA Court, when applying the Albany exclusion to the equivalent provisions of the EEA Agreement in a case concerning a collectively agreed pension scheme found that "conditions of work and employment" must be interpreted broadly', ${ }^{38}$ while cautioning that 'more circumstantial detail' might disqualify a collective agreement for the exception. ${ }^{39}$ The $2^{\text {nd }}$ Albany criterion was again tested in the AGR2 case in $2011,{ }^{40}$ with the argument that a scheme not allowing to apply for nonaffiliation would also not allow more favourable insurers for employees. This argument was rejected, since the purpose of providing health care cover suffices for the collective agreement to pursue the

\footnotetext{
32 Paragraph 59

${ }^{33}$ Paragraphs 55, 56

34 Paragraph 62

35 Paragraph 59

${ }^{36}$ (Nordling, 2015, p. 42).

${ }^{37}$ van der Woude C-222/98, EU:C:2000:475.

${ }^{38}$ E-8/00 Norwegian Federation of Trade Unions para 53.

39 Ibid para 55.

${ }^{40}$ AG2R Prevoyance C-437/09, EU:C:2001:112.
} 
purpose of improving working and employment conditions. The limits of the second Albany condition were thus far only met in the FNCBV case, concerning an agreement between slaughterhouses and small farmers on prices for slaughtering animals and the suspension of imports after farmers' blockades of lorries in connection with the mad cow disease. The General Court found that 'the agreement does not relate to measures for improving conditions of work and employment, but to the suspension of beef imports and the fixing of minimum prices for certain categories of cows' ${ }^{41}$ In summary, the Court generally interprets the second Albany criterion broadly and, in particular, found that it was fulfilled by the social security funds based on collective agreement in the 1999 cases.

\section{Collective agreements and abuse of a dominant market position}

Even if not classing a collectively agreed social security scheme as anti-competitive under Article 101 TFEU, the Court did not hesitate to apply Article 102 TFEU to the institutions which were providing the schemes. ${ }^{42}$ In the $A G 2 R$ case, the Court did see the potential of the institution not being an undertaking (and thus outside the scope of the competition provisions) due to its high degree of solidarity, but left the final determination to the national court. In Pavlov ${ }^{43}$ the scheme was considered an undertaking with a dominant market position, though the Court did not find any abuse. In the other cases, the schemes were accepted as exempted under Article 106 (2) TFEU as services in the general economic interest.

While, therefore, in the end, none of the social security schemes constituted infringements, this was either because one of the criteria of Article 102 TFEU had not been met or due to the exemption under Article 106 (2) TFEU. It was, significantly, not because there was an exclusion from Article 102 TFEU per se such as the 'Albany exclusion' from Article 101 TFEU. Depending on the specific schemes, institutions set up by collective agreement could thus still potentially infringe Article 102 TFEU irrespectively of whether or not the agreement itself fell under Article 101 TFEU or not.

\section{Collective bargaining for micro-entrepreneurs and EU competition cases}

The question whether the trade union signing the collective agreement represents workers $\left(1^{\text {st }} \mathrm{Al}\right.$ bany criterion) is particularly relevant in recognising collective bargaining rights of micro-entrepreneurs. While this was no particular problem in the three 1999 cases (Albany, Brentjens and Drijvende Bokken), it was discussed more thoroughly in subsequent case law, which we analyse in this section.

In the Pavlov case, the Court refused to recognise an agreement setting up a pension fund for selfemployed medical consultants as collective agreement, because the consultants were not employees. The agreement was nevertheless not considered as infringing Article 101 (1) TFEU because it did not appreciably prevent, restrict or distort competition (i.e. it was de minimis). ${ }^{44}$

\footnotetext{
${ }^{41}$ FNCBV T-217/03 and T-245/03 EU:T:2006:391, paragraph 100.

42 The EFTA Court (see above note 38 ) had not assessed this.

43 Pavlov C-180-184/98, EU:C:2000:428.

44 Ibidem.
} 
In FNCBV,$^{45}$ the General Court also found that the first Albany condition was not met. Disregarding the French Labour Code,${ }^{46}$ it considered the farmers as undertakings, ${ }^{47}$ among other things because they did not work under the direction of the slaughterhouses. ${ }^{48}$ As this aspect was not part of the appeal to the ECJ, the role of a statutory expansion in national law of the notion of workers for the purpose of collective bargaining was not clarified.

More recently, the limitation of the first Albany condition was tested before the Court in the FNV Kunsten case, ${ }^{49}$ which also took the case law into more central areas of collective bargaining such as determining remuneration. The Dutch competition authority had published a position that a collective agreement on payment for substitutes for orchestra musicians was infringing competition law because it also applied to those substitutes, who were hired under a contract of services, not of employment. FNV Kunsten, a trade union, challenged this position paper as it had led the employer organisation and the other trade union involved to terminate the agreement and to refuse to renegotiate pay for the self-employed substitutes. In his opinion, AG Wahl had rejected the authority of collective agreements to cover micro entrepreneurs whose economical position is comparable to that of workers. Yet, Wahl floated the idea that a collective agreement fixing wages for the self-employed could still qualify as aiming to improve working conditions of employees, if it aimed at protecting workers from "social dumping" [sic] by preventing contracts with independent musicians for lower remuneration. ${ }^{50}$

The Court took another route by focusing on who would qualify as a worker/labour in the sense of the first Albany condition. Repeating that the notion of workers under EU law may differ from that under national law, the Court relied on its case law in the field of free movement of workers ${ }^{51}$ and equal pay for equal work irrespective of gender ${ }^{52}$ as well as on the previously discussed case Becu. Arguably, it developed a specific notion of worker for the purposes of competition law, which determines whether micro-entrepreneurs qualify as undertakings, which are subject to competition law or as workers which are excluded from competition law coverage when bargaining collectively. The Albany exclusion from Article 101 TFEU is thus not accepted for those micro entrepreneurs who cannot be considered as falsely self-employed under this definition. These micro entrepreneurs would still be subject to the control of competition authorities when organising collectively to improve their working conditions. ${ }^{53}$ The Court's definition reads:

\section{3 [...] [A] service provider can lose his status of an independent trader, and hence of an undertaking, if he does not determine independently his own conduct on the market, but is entirely dependent on his principal, because he does not bear any of the financial or commercial risks arising out of the latter's activity and operates as an auxiliary within}

\footnotetext{
${ }^{45}$ FNCBV above note 41, para 100.

${ }^{46}$ Paragraph 58

${ }^{47}$ Paragraph 48-50

48 Paragraph 100.

${ }^{49}$ FNV Kunsten Informatie en Media C-413/13 ECLI: EU:C:2014:2411.

${ }^{50}$ Paragraph 76-78 of his opinion.

${ }^{51}$ N. C-46/12 EU:C:2013:97, paragraph 40 and the case-law cited.

52 Allonby C-256/01, EU:C:2004:18, paragraph 71.

${ }^{53}$ A more optimistic assessment is provided by (Klebe \& Heuschmid, 2016, p. 182) and hinted at by (de Stefano, 2016).
} 
the principal's undertaking (see, to that effect, judgment in Confederación Española de Empresarios de Estaciones de Servicio, EU:C:2006:784, paragraphs 43 and 44).

$[\ldots]$

36 It follows that the status of 'worker' within the meaning of EU law is not affected by the fact that a person has been hired as a self-employed person under national law, for tax, administrative or organisational reasons, as long as that persons acts under the direction of his employer as regards, in particular, his freedom to choose the time, place and content of his work (see judgment in Allonby, EU:C:2004:18, paragraph 72), does not share in the employer's commercial risks (judgment in Agegate, C-3/87, EU:C:1989:650, paragraph 36), and, for the duration of that relationship, forms an integral part of that employer's undertaking, so forming an economic unit with that undertaking (see judgment in Becu and Others, C-22/98, EU:C:1999:419, paragraph 26) [emphasis added].

This reasoning aspires to forge a specific notion of workers for competition law purposes which includes those who are wrongly classed as self-employed. While the Court refers to working under the direction of another, highlighting dependency as the criterion traditionally used to establish worker status in labour law, ${ }^{54}$ it also makes reference to more economic criteria such as sharing of commercial risk, and being integrated into the organisation of another. In adapting labour law to the needs of the modern, interconnected economy, the criterion of economic dependency has been discussed widely. However, the FNV Kunsten ruling seems to require organisational integration and in addition economic dependency. If those criteria are cumulative, the definition will not cover all gig workers: while most of them are economically dependent, many are not organisationally dependent. They would have to be classed as self-employed. Any collective agreements negotiated on their behalf would risk being subjected to the control of EU competition law.

\section{Safeguarding collective labour rights for gig-workers - making smart cities smarter?}

In this section, we first discuss the rationale for granting gig-workers collective bargaining rights and argue that the opportunity of organising collectively could remove a structural barrier for making the smart city an equitable place to work and live.$^{55}$ This is followed by a short section why outlawing collective bargaining of gig-workers under competition law is particularly problematic. In the remainder of the section we develop arguments for a reinterpretation of EU competition law. These re-interpretations would remove the threat of being fined and prosecuted by competition authorities for collective bargaining in favour of gig-workers. It would thus enable gig workers to organise and to voice demands for fairer working conditions adapted to the specific characteristics of the sector. Initially we submit that the ECJ case law as it stands already provides avenues for a more economically oriented interpretation of the notion of workers. We then develop a more substantial reinterpreta-

\footnotetext{
${ }^{54}$ See on this (Davidov, et al., 2015; Waas \& van Voss, 2017, pp. 44-52)

${ }^{55}$ See on the connection above, text surrounding footnotes 1 to 10 .
} 
tion which would, ideally, exclude collective agreements from the scope of Article 101 (1) TFEU. Alternatively, we also propose arguments that would allow interpreting Article 101 (1) TFEU in a way that no infringement would be found through a collective agreement.

\section{Rationale for collective bargaining of gig workers}

Generally, features of work in the gig-economy contribute to pressure on gig-workers to become more and more productive, which may lead to spiralling working hours inversely related to increase in earnings. Both crowd and app-workers, in particular if denied the protection of employment law and social insurance, can be classed as part of the new precariat. ${ }^{56}$ As these micro entrepreneurs only trade in their personal labour, the paradox observed on employment markets would apply to them as well: the workers of industrial times, never able to accrue sufficient assets to allow them to bridge periods without work, were driven into a murderous competition by this economic incentive to undercut others by accepting lower wages. This would lead to an expansion, instead of a contraction of labour made available. This again induces a negative spiral of competition, which collective bargaining was designed to interrupt, and indeed to convert. In the case of the gig workers, the economic incentives are complemented by effects of the computerised evaluation and rating instruments, which encourage workers to underbid (if crowd working) or to outperform each other (if app working). ${ }^{57}$

This chimes with the earliest justification of collective bargaining: it sought to correct the structural imbalance of labour markets to the detriment of workers by allowing them to combine as well as to take collective industrial action. ${ }^{58}$ The economic dependence of gig-workers underlines the currency of these market-based justifications for collective bargaining rights fort those who offer their services in the gig-industry: as individuals, without having accrued sufficient assets to allow them to bridge periods without work, they are relatively powerless against those requiring their services. This is independent from their classification as employees, workers or self-employed micro-entrepreneurs. ${ }^{59}$ What is more, despite counter-evidence by high profile court cases around classification as workers, some gig-workers seem to appreciate the status of being self-employed: ${ }^{60}$ the related independence gained (even if illusionary) is viewed as one of the advantages of gig work. Accordingly, retaining status-independence while collectively bargaining would be an advantage.

Next to the market-based justifications for collective bargaining, human rights guarantees of collective bargaining (e.g. Articles, 12 and 28 Charter of Fundamental Rights for the European Union) rest on more fundamental deliberations. The right to combine and engage in relation to working conditions also empowers citizens to take political engagement from the narrow realm of the traditional public sphere to the wider realm of the market place. Participatory citizenship thus extended to the market place as a form of social citizenship ${ }^{61}$ also suggests that securing humane working conditions through self-determination of workers is superior to relying on protective state legislation. Collective

\footnotetext{
${ }^{56}$ This is also raised as a critique of smart cities, due to their reliance on gig-work, see for example (Sadowski \& Pasquale, 2015)

${ }^{57}$ See with some empirical evidence from the UK, the Netherlands, Germany, Austria and Sweden (Huws, et al., 2016).

58 (Hickel, 2007) (Kaufman, 2010/11) (Reichold, 2010) (Stützel, 1979) (Schiek \& Ulber, 2016).

${ }^{59}$ On this distinction see above footnotes 20-22.

60 (Taylor, et al., 2017, pp. 74-76)

${ }^{61}$ See on this (Schiek, 2017, pp. 345-350).
} 
bargaining as joint regulation based on these additional justifications goes beyond pressurising for just wages and working times, and encompasses establishing a working environment facilitating the actual enjoyment of fundamental rights more generally in the work place.

These justifications for collective bargaining derived from the need for persons to self-govern acquire a specific urgency in the gig-industry. Whether its appwork or crowdwork, techniques for building trust in the anonymous person with whom the service recipient connects are pivotal for their success. These techniques require workers to provide personal information at every corner and allow for constant customer ratings which may be demeaning, causing emotional stress, but still unchangeable. Maintaining some boundaries around personal life becomes a regulatory challenge which app- and crowd-workers can better master collectively. Securing data protection and a realistic private sphere constitute examples of regulatory needs that can be addressed by collective bargaining, complementing legislation if it applies or, in the case of the gig-economy, filling gaps left by legislation.

Further, the fast-paced gig economy makes accruing savings for ill health, times of low demand for work or when the "gigger" needs to prioritise other tasks such as childcare or further education, difficult. Even from within the gig economy, a discussion has started on how to provide portable security systems which reward the flexibility of working on changing platforms or with different apps instead of deterring from diversifying and moving. ${ }^{62}$ Collective bargaining as a regulatory technique has the advantage of allowing rules tailored to the needs of sectors in this regard. Indeed, in the early stages of industrialisation the mutualisation of risks of micro-entrepreneurs not yet recognised as workers constituted a viable form of pre-collective bargaining. ${ }^{63}$

At the same time, specific features which the gig-economy shares with smart city may render collective organisation difficult: the reliance on technology allows working and engaging without personal contact, thus leading to efficiency gains by individualisation and reduction of face to face communication. While this may be typical for other forms of precarious employment as well, it is enhanced by IT-based work. On the other hand, gig-work also offers specific opportunities to contact workers: web based services that can adapt to the small windows of time left in the day of a gig-worker, who is relying on information technology for a living, might be the key.$^{64}$ While gig workers may embrace individuality, they could still appreciate services ${ }^{65}$ such as training for professional qualifications, induction to ways of avoiding giving up more privacy than is necessary for being successful in gig-work or general ways of managing time in the gig-economy. Even those sceptical of trade union representation and other traditional employment law stress the value of web-based forms of organisation of self-employed workers. ${ }^{66}$

\footnotetext{
62 (Forde, et al., 2017; Taylor, et al., 2017)

63 (Cella, 2012).

${ }^{64}$ The platform http://faircrowd.work/, by the German IG Metall and the Swedish Unionen, with input by the UK Independent Workers Union, the Austrian Trade Union Congress and an US American trade union for gigworkers is a first step towards this, see also (Klebe \& Heuschmid, 2016; Körfer \& Röthig, 2017)

${ }^{65}$ On the general relevance of the service function of trade unions see, e.g., (Ewing, 2005).

${ }^{66}$ See (Balaran, et al., 2017, pp. 57, 67), promoting coregulation and government funded cooperative platforms supporting workers, and (Taylor, et al., 2017, pp. 75-77), culminating in unspecified Workertech solutions.
} 
There are thus good arguments to use collective bargaining as a regulatory technique in the gig-industry, alongside wider reasons to provide options of engagement and self-governance more adequate for modern smart cities than state regulation. We argue that such activities would suffer disproportionally if subjected to the control of competition law. EU competition law is enforced by a network of specialised administrations, which react fast and flexible potentially imposing considerable fines. The judicial review mechanisms are geared to the needs of large corporations, and would fast deplete the resources of the initially small organisations of micro-entrepreneurs in the gig industry, and even of traditional trade unions. This would obstruct emerging collective bargaining structures, although these very structures would be well suited to introduce standards of fairness allowing the gig-industry and smart cities to live up to ideals allured to by notions such as "sharing economy". For example, ring-fencing agreements, consisting of promises by "giggers" to each other not to engage any app or a crowd-working platform not agreeing to certain minimum prices or minimum data protection would risk attracting the wrath of the competition authorities. This is evidenced by a recent ECJ case following a decision by a national competition authority to fine a professional organisation of geologists because they recommended minimum fees for their self-employed members. ${ }^{67}$ Similar risks would be encountered by the "workertech" solutions proposed in the UK if these offer collaborative platforms for self-employed gig-workers enabling them to "navigate the challenges of the modern economy", ${ }^{68}$ as well as by the collaborative regulation and cooperative organisations supported by the RSA report. ${ }^{69}$ If those new organisations would agree the creation of portable benefit platforms with owners of apps and crowd-platforms, ${ }^{70}$ these agreements may be found to violate simultaneously prohibitions of cartels and abuse of a dominant market position, ${ }^{71}$ which again could result in higher fines than just for finding an infringement of one article.

\section{Changing the argument in case law}

In developing new ways for the ECJ to change its case law on the relation of competition law and collective bargaining in the light of the EU's constitutional values, ${ }^{72}$ we propose a way to overcome the dilemmas outlined above. While the case law has not yet referred to the changes demanded by the gig economy, there are a number of formal anchoring points for progress, which can be developed further.

\section{a) A functional interpretation of the notion of "worker" for the purposes of competition laws}

Developing a functional notion of "worker" for the purpose of competition law would constitute one option to safeguard collective bargaining in the gig-economy as a sector characterised by precariousness and a high proportion of micro-entrepreneurs. While labour lawyers also debate new models of defining worker and employment status, ${ }^{73}$ this is not our theme and neither do we attempt to de-

\footnotetext{
${ }^{67}$ Consiglio nazionale dei geologi and Autorità garante della concorrenza e del mercato Case C-136/12, EU:C:2013:489

68 (Taylor, et al., 2017, p. 76)

69 (Balaran, et al., 2017, p. 57)

70 Ibidem

${ }^{71}$ See discussion above section III.

72 (Schiek, 2015).

${ }^{73}$ See (Taylor, et al., 2017, pp. 74-79; Waas, et al., 2017)
} 
cide the dispute on whether the flexibility of the labour law definition of worker and employee status is a weakness ${ }^{74}$ or a strength due to its capacity to adapt to new developments, technological or otherwise. ${ }^{75}$ Instead, we consider whether defining the notion of worker in specific ways for the purposes of competition law would contribute to enabling gig-workers of all categories to engage in collective bargaining.

So far, there is no ECJ case law on the classification of gig-workers. The Court's first ruling on "Uber"76 concerned the question whether Uber is a transport service under Article 2(2) Directive $2006 / 123$ or a service in the information society under Directive 2000/31, which was decisive for the question whether Spain could require registration before operation. AG Spzunar considered that answering the question whether Uber offered a brokering platform or a transport service required a decision on whether Uber controlled its drivers, which he argued was the case. ${ }^{77}$ The Court followed its AG, stating that "Uber exercises decisive influence over the conditions under which that service is provided by those drivers", including determination of the "maximum fare by means of the eponymous application" (...) as well as "the quality of the vehicles, the drivers and their conduct", connected with the power to exclude drivers. ${ }^{78}$ This would indicate that Uber drivers are under the direction of someone else for a certain period of time and receive remuneration, and would thus be qualified as workers under ECJ case law. The assessment of worker status in the app-model of gig work might thus be similar to the assessment under national laws. ${ }^{79}$ As under national laws, not all those contracting with "apps" would be classed as workers, and these considerations would not apply to the crowd-model of gig work at all. Accordingly, a relevant section of services in the gig-economy; in particular under the crowd model will be delivered by genuinely self-employed persons.

It is thus worthwhile proposing an expansion of the criteria the Court has chosen for defining the notion of worker, as confirmed in FNV Kunsten. Under that definition a worker works under the direction of another. However, the lines dividing self-employed and employed workers become more blurred when it comes to economic independence and the bearing of commercial risk: for example, the mere fact that someone is paid in a share of the commercial success of his or her employer does not defy his or her worker status, although this form of remuneration relocates the commercial risk to the worker. ${ }^{80}$

Also, the Court in FNV Kunsten as well as in Becu pointed to the relevance of the worker being incorporated into the undertaking of the employer for the time of the contract. This relates to another doctrine for the scope of application of competition law, the single economic unit doctrine: competition law only applies to relations of those undertakings, which actually compete with each other on

\footnotetext{
74 That is the view of the Taylor report.

75 See for such a conclusion, from a comparative law perspective (Waas \& van Voss, 2017)

${ }^{76}$ Elite Taxi, C-434/15.

77 Opinion of 11 May 2017 ECLI:EU:C:2017:364, paragraph 44. While the case did not concern competition law, AG Spzunar did indicate that if Uber would merely facilitate matching, it would probably infringe EU competition law (paragraph 62).

78 Grand Chamber judgment of 20 December 2017, ECLI:EU:C:2017:891, paragraph 39

${ }^{79}$ See above section II.

${ }^{80}$ The Court referred to the judgment in Agegate 3/87, EU::1989:650 for this line of argument.
} 
the market. While nowadays this line of case law is mainly relevant for conglomerates of undertakings, ${ }^{81}$ the Court has, in earlier cases, also considered the relationship between a self-employed agent and the principal as an example where EU competition law does not apply because both form one economic unit. ${ }^{82}$ By contrast, publicans, whose pub was leased to them by the brewery, and who were only allowed to sell that brewery's beer, were viewed as sufficiently independent economically to not form an economic entity with the brewery. Accordingly, a collective agreement between the publicans and the brewery was subject to EU competition law. ${ }^{83}$ When and in how far the single economic unit doctrine can be applied to individuals to determine whether they are part of another undertaking thus remains somewhat unclear.

Overall, this case law invites us to redefine the dividing line between those service providers to whose collective bargaining activities competition law never applies (as per Becu) and those whose collective agreements may be classed as cartels or abuse of a dominant market position. The former would encompass those formally self-employed persons who form an economic unit with their main trading partner, while not working under their direction as with an employer. The case law presently demands that the trading partner also assumes (most of) the commercial risk. In the gig-economy (as well as in other sectors engaging in precarisation) multinational companies and other employers endeavour to shift the commercial risk onto the economically dependent self-employed persons. We would suggest that a truly economic approach to the notion of worker would recognise that this shifting of risk is an expression of economic dependency on the part of the worker or micro-entrepreneur. Those contractors unable to shift the risk individually to their counterpart would be enabled to avail of collective bargaining techniques in order to create a fairer market place for all, and thus enhance the legitimacy of the gig economy.

All this means that the first condition of the Albany exclusion should be rephrased through a functional interpretation of the notion of undertaking in EU competition law. This would support an exclusion for all collective bargaining processes aimed at overcoming economic dependency of economically dependent service providers, irrespective from whether they are self-employed or not. This would go well beyond the FNV Kunsten case law, as it would become unnecessary to class the micro-entrepreneurs as falsely self-employed. The change would, however, build on the definition of a worker developed in FNV Kunsten. As mentioned, the Court in FNV Kunsten required - in line with earlier case law - that a worker must not assume the employer's commercial risk. ${ }^{84}$ However, shifting the commercial risk of the providers (such as Uber) to the freelance workers constitutes a central characteristic of app-work as well as of crowd work. Similar to the notion of worker for competition law purposes developed above, a focus on commercial/economic dependence instead of on risk (personal dependence) thus constitutes a way forward for determining which agreements would be excluded from Article 101 (1) TFEU. This would not only be adequate for the crowd and app work, but also for other forms of non-standard work. Furthermore, it would be in line with the single economic unit case law: if the gig -worker is commercially dependent on the platform, she would usually not be able to act independently, and thus be integrated in the platform unit. Therefore, it is not sufficient for the platform operator to formally shift the commercial risk to the crowd- or app-

\footnotetext{
${ }^{81}$ For an overview see (Odudu \& Bailey, 2014).

82 Suiker Unie 40-8, 50, 54, 56, 11, 113-4/73, EU:C:1975:174, paragraph 539.

${ }^{83}$ Brasserie de Haecht 23/67, EU:C:1967:54.

${ }^{84}$ See above section III 3.
} 
worker. Instead, collective agreements of persons who are economically dependent, for example because they do not have an organisation sufficiently large to allow them to diversify to more than 3 or 4 platforms, remain excluded from Article 101 (1) TFEU.

b) Auxiliary roads: collective labour agreements to avoid adverse competition by selfemployed workers and ancillary restraints

There is also another possibility to exclude collective agreements from the scope of Article 101 (1) TFEU, similar to what was floated by AG Wahl in the FNV Kunsten case. He suggested accepting the competition immunity of a collective agreement in favour of independent contractors if the trade union involved seeks to protect their worker members through an anti-social dumping strategy. This would mean that trade unions can demand to include tariffs for independent contractor for such posts which are also filled by workers. Especially for the gig-industry, this would protect the newly won collective bargaining rights from negative impact deriving from divisions within those servicing the gig-economy. A partition of these will be independent contractors who work in the crowd or on the app as a hobby and are not dependent on the earnings. Gig workers and their trade unions could bargain for tariffs binding these actors, although they are not commercially dependent.

If a collective bargaining agreement was to fall under Article 101 (1) TFEU, the Court would still have the opportunity to interpret that article in a way that the agreement would not be seen as anti-competitive. If the Court would, for example, not automatically assume an agreement on wages as an object restriction, the effects of the agreement could be assessed more broadly. For example, arguably, low pay for gig-worker could drive other undertakings out of the market, which ultimately would lead to less competition. Although the General Court excluded the notion of a rule of reason under Article 101 (1) TFEU, ${ }^{85}$ the Court and General Court have sometimes conducted a broader analysis. ${ }^{86}$ Our proposal thus could be reconciled with existing case law. ${ }^{87}$

Furthermore, and more importantly, the Court itself has accepted in case law decided around the time of Albany, Breentjes and Drijvende Bokken that there could be ancillary restraints in agreements which do not in themselves have the object or effect of restricting competition. The Wouters case, on a clause in the regulations issued by the Dutch Bar association, had to deal with the question whether professional rules of conduct prohibiting firms consisting of both solicitors and accountants would conflict with competition rules. The Court found that this is not the case because the "consequential effects of restricting competition" were "inherent in the pursuit" of other objectives which were at the heart of the professional organisations' purpose. ${ }^{88}$ This could equally be an adequate instrument to allow a more principled argument around justification from Article 101(1) TFEU in favour of collective agreements. Collective bargaining, resulting in agreements and underpinned by credible threats of collective industrial action, are necessary in order to allow workers to achieve acceptable working conditions in a self-organised way. If structures of a sector, such as the

\footnotetext{
85 Métropole, T-112/99, EU :T :2001:215

${ }^{86}$ For an overview see (Jones \& Sufrin, 2016, p. 271 seq).

${ }^{87}$ See similar with regards to environmental protection and suggesting that the net competitive effects of an agreement could be considered at the Article 101 (1) TFEU stage, while then other benefits could be considered at the Article 101 (3) TFEU stage (Monti \& Mulder, 2017, p. 644 seq).

${ }^{88}$ Wouters C-309/99 EU:C:2002:98, paragraph 97, confirmed in case Meca-Medina C-519/04P EU:C:2006:492, paragraph 45 .
} 
gig-economy, should be addressed, it also seems preferable to recover multi-employer bargaining in the form of multi-platform bargaining. ${ }^{89}$ This argumentation seems to fit neatly with the areas in which the Wouters case law has been applied in that it usually concerned public goods and areas of state 'support for self-regulation'. ${ }^{90}$

Of course, there would also be other possibilities in which a collective agreement could be considered as not infringing Article 101 (1) TFEU. As mentioned, the Court held in Pavlov that the agreement on assigning self-employed medical practitioners to a healthcare fund did not have an appreciable effect on competition within the sector. ${ }^{91}$ Yet, these would seem more incidental to the specific case.

\section{c) Avoiding competition law hurdles for collective bargaining in the gig-economy} Combining a re-interpretation of the notion of worker specifically for competition law with a functional re-interpretation of the Albany exclusion constitutes a convincing and compelling route to avoid collective labour agreements from being captured by Article 101 TFEU. This interpretation frees collective bargaining from the supervision by competition authorities, which would clash with the autonomy of collective bargaining. Nevertheless, the other routes, though less satisfactory, also would achieve some progress. The re-interpretation of collective agreements as not having the object or effect to hinder competition despite some potential ancillary restraints along the Wouters case law would present the next preferable option.

\section{Conclusion}

It has become a truism to state that the gig-economy poses challenges for labour law and, in particular, for collective bargaining. However, the role of EU competition law in compounding these challenges has received limited attention. While the narrow approach of the Court on exempting collective labour agreements from coverage of EU competition law has been criticised in literature, its specific impact on the gig economy has not been thoroughly analysed. The FNV Kunsten ruling has proposed a wide notion of worker, based on a functional reading of the organisation of work. Yet, it remains focused on organisational dependence, resulting in qualifying many gig-workers, especially crowd workers, as self-employed. The Court's reluctance to protect collective bargaining rights of self-employed workers from the wrath of competition law thus threatens the emerging collective bargaining structures in the gig-economy specifically.

This article addresses the lack of academic debate in this field and proposes a re-interpretation of EU competition law based on an analysis of the interface of smart technology in the gig-economy and EU competition law. EU guarantees of collective labour rights and the need to preserve the European Union's enhanced socio-economic model demand that gig-workers' opportunities to bargain collectively and to threaten their employers with collective action should not be compromised by

\footnotetext{
${ }^{89}$ See for a similar argument (Kovacs, 2017, pp. 101-102) in relation to telework.

90 (Monti \& Mulder, 2017, p. 646 seq).

${ }^{91}$ However, the case law on appreciable effects (de minimis) has suffered in relevance from the Expedia ruling of 2012 (Expedia C-226/11, ECLI:EU:C:2012:795), since the Court no longer recognises agreements which have the object of limiting competition. Whether this threatens collective bargaining agreements, depends on whether any potential hindrance of competition would be regarded as object restriction or effect restriction which may go back to whether one focuses more on the human rights or more on the market related justifications of collective bargaining.
} 
subjecting any resulting collective labour agreements to competition law control. We propose several routes to achieve this aim, expanding various anchors in case law and AG opinions to achieve a comprehensive adaptation of EU competition law to smart employment markets. Using a competition-law specific notion of workers, which should focus on economic criteria, in combination with recognising a functional exclusion of collective bargaining agreements from EU competition law by expanding the "Albany exclusion" emerges as the most promising road. This original solution can be anchored in past developments of the Court's case law. Our approach thus constitutes a realistic way forward and a genuine opportunity to avoid clashes between competition law and collective labour rights.

Beyond the issues it causes for a particular collective agreement and the workers involved, the potential clash between EU competition law and collective bargaining in the gig-economy also endangers the emerging transnational trade union activities in the sector. Furthermore, it limits the options for national legislation extending collective bargaining rights to gig-workers and other marginal independent contractors given that state action can partly equally be challenged under the competition provisions. Revising the limiting doctrine of the Court of Justice in this field is thus relevant to the future shape of the gig-economy as well as the adaptation of labour law to its demands. This article has not only demonstrated the necessity to argue in favour of such changes, but also proposed a solution.

\section{Bibliography}

Almirall, E. et al., 2016. Smart Cities at the Crossroads: New Tensions in City Transformation. California Management Review, 59(1), pp. 141-152.

Aloisi, A., 2016. Comoditized Workers: Case Study Research on Labour Law Issues Arising From a Set of "On-Demand/Gig Economy" Platforms, 37, 653-690; . Comparative Labour Law and Policy Journal, Volume 37, pp. 653-690.

Aspinall, A. \& Smith, E. A., 1959. English Historical Documents XI, 1783-1832. New York: OUP. Balaran, B., Warden, J. \& Wallace-Stephens, F., 2017. Good Gids. A fairer future for the UK's gig economy. London: RSA.

Berg, J., 2016. Income Security in the on-demand economy. Findings and Policy Lessons from a Survey of Crowdworkers. Comparative Labor Law \& Policy Journal, 37(3), pp. 543-576.

Bruun, N. \& Helsten, J., 2001. Collective Agreement and Competition Law in the EU. Helsinki: University Centre of International and Economic Law.

Cardulllo, P. \& Kitchin, R., 2017. Being a 'citizen' in the smart city: Up and down the scaffold of smart citizens participation. Programmable City Working Papers.

Cella, G., 2012. The representation of non-standard workers. Theory and culture of collective bargaining. Transfer, 18(2), pp. 171-184.

Cherry, M., 2016. Beyond MisclassificationL The Digital Transformation of Work. Comparative Labor Law \& Policy Journal, Volume 37, pp. 577-600. 
Cocchia, A., 2014. Smart and Digital City: A Systematic Literature Review. In: R. P. Dameri \& C. Rosenthal-Sabroux, eds. Smart City. Progress in IS. Vienna: Springer International, pp. 13-43.

Davidov, G., Freedland, M. \& Kountouris, N., 2015. The subjects of labour law: 'Employees' and other workers. In: M. Finkin \& G. Mundlak, eds. Comnparative Labour Law. Cheltenham: Edward Elgar, pp. 115-131.

de Stefano, V., 2016. The rise of the "just-in-time workforce": On-demand work, crowdwork und labour protection in the "gig-economy". Geneva: ILO.

Degryse, C., 2016. Digitalisation of the economy and its impact on labour markets. Brussels: European Trade Union Institute.

Eurofund, 2015. New Forms of Employment. Luxembourg: Office of Publication for the European Union.

Ewing, K., 2005. The Function of Trade Unions. Industrial Law Journal, 34(1), pp. 1-32.

Finkin, M., 2016. Beclouded Work, Beclouded Worker in Historical Perspective. Labor Law \& Policy Journal, Volume 37, pp. 603-618.

Forde, C. et al., 2017. The Social Protection of Workers in the Platform Economy. Brussels: Policy Department A of the European Parliament.

Glasmeier, A. \& Christopherson, m. S., 2015. Thinking About Smart Cities. Cambridge Journal of Regions, Economy and Society, 8(1), pp. 3-12.

Hatzopolous, V. \& Roma, S., 2017. Caring for Sharing? The Collaborative Economy under EU Law. C.M.L.Rev., 54(1), pp. 81-128.

Hickel, R., 2007. Kritische Hinweise zu P. Kalmbach über Mindestlöhne in Deutschland. Wirtschaftsdienst, 3(10), pp. 696-698.

Huws, U., Spencer, N. \& Joyce, S., 2016. Crowd Work in Europe. Preliminary results from a survey in the UK, Sweden, Germany, Austria and the Netherlands. Brussels: Foundation for Progressive European Studies.

ILO, 2016. Non-standard employment around the world. Understanding challenges, changing the prospects. Geneva: ILO.

Jones, A. \& Sufrin, B., 2016. EU Competition Law. 6th ed. Oxford: OUP.

Kaufman, B. E., 2010/11. The Theoretical Foundation of Industrial Relations and its Implications for Labor Economics and Human Resource Management. Industrial Labour Relations Review, 64(1), pp. 74-108.

Kenney, M. \& Zysman, J., 2016. The Rise of the Platform Economy. Issues in Science \& Technology, Issue Spring, pp. 61-69. 
Klebe, T. \& Heuschmid, J., 2016. Collective Regulation of Contingent Work: From Traditional Forms of Contingent Work to Crowdwork - A German Perspective. In: E. Ales, O. Deinert \& J. Kenner, eds. Core and Contingent Work in the European Union. Oxford: Bloomsbury, pp. 176-197.

Koerfer, A. \& Roethig, O., 2017. Decent crowdwork - the fight for labour law in the digital age. Transfer, 23(1), pp. 233-236.

Körfer, A. \& Röthig, O., 2017. Decent crowdwork - the fight for labour law in the digital age. Transfer: European Review of Labour and Research, 23(2), pp. 233-236.

Kovacs, E., 2017. Do We Really Wish You Were Here? Hungary and Distance Work. In: E. Ales, O. Deinert \& J. Kenner, eds. Core and Contingent Work in the European Union. New York: Bloomsbury, pp. 79-110.

Lougher, G. \& Kalmanowicz, S., 2016. EU Competition Law in the Sharing Economy. Journal of European Competition Law, 7(2), pp. 87-102.

Monti, G. \& Mulder, J., 2017. Escaping the clutches of EU competition law. European Law Review, 42(5), pp. 635-656.

Nordling, H., 2015. State of the unions: the applicability of Article 101(1) TFEU to collective bargaining agreements after FNV Kunsten Media. Competition Law Journal, pp. 37-48.

Odudu, O. \& Bailey, D., 2014. The Single Economic Entity Doctrine in EU. C.M.L.Rev., 51(6), p. 17211758.

Ratti, L., 2017. Online Platforms and Crowdwork in Europe: A Two Step Approach to Expanding Agency Work Provisions?. Comparative Labor Law \& Policy Journal, 38(3), pp. 477-511.

Reichold, H., 2010. Entmachtung des Tarifkartells durch neues Kartellrecht?. In: M. Martinek, P. Rawert \& B. Weitemeyer, eds. Festschrift Dieter Reuter. Berlin: De Gruyter, pp. 759-777.

Sadowski, J. \& Pasquale, F., 2015. The Spectrum of Control: A Social Theory of the Smart City. [Online] Available at: http://firstmonday.org/article/view/5903/4660

Schiek, D., 2015. A constitution of social governance for the European Union. In: N. Ferreira \& D. Kostakopoulou, eds. The Human Face of the EU. Cambridge: CUP, pp. 17-47.

Schiek, D., 2017. Perspectives on Social Citizenship in the EU: From Status Positivus to Status Socialis Activus via Two Forms of Transnational Solidarity. In: D. Kochenov, ed. EU Citizenship and Federalism. Cambridge: CUP, pp. 341-370.

Schiek, D., Oliver, L., Forde, C. \& Alberti, G., 2015. EU Social and Labour Rights and EU Internal Market Law. Brussels: European Union.

Schiek, D. \& Ulber, D., 2016. Tarifvertrag und nationales und supranationales Kartellrecht. In: W. Daeubler, ed. Tarifvertragsgesetz. Baden-Baden: Nomos, pp. 193-204.

Schmid-Drüner, M., 2016. The situation of workers in the collaborative economy. In depth analysis. Brussels: European Parliament. 
Stützel, W., 1979. Paradoxa der Geld- und Konkurrenzwirtschaft. Aalen: Scientia.

Sundararajan, A., 2016. The Sharing Economy. The End of Employment and the Rise of Crowd Based Capitalism. Cambridge, Massachusetts \& London, England: The MIT Press.

Taylor, M., Marsch, G., Nicol, D. \& Broadbent, P., 2017. Good Work. The Taylor Review of Modern Working Practices. London: s.n.

Valenduc, G. \& Vandrame, P., 2016. Work in the Digital Economy: Sorting the Old from the New. Brussels: European Trade Union Institute.

Waas, B., Liebman, W., Lyubarsky, A. \& Kezuka, K., 2017. Crowdwork - A Comparative Law Perspective. Frankfurt a M: Bund.

Waas, B. \& van Voss, G. H. eds., 2017. Restatement of Labour Law in Europe, Volume I: The Concept of Employee (Oxford et al Hart 2017). Oxford: Hart.

Wish, R. \& Bailey, D., 2015. Competition Law. 8th ed. Oxford: OUP. 